\title{
Assessing the Impact of the COVID-19 Crisis on the Socio- Economic Situation in Africa
}

Ebrima K. Ceesay, University of the Gambia, Banjul, Gambia

\begin{abstract}
This article assesses the impact of the COVID-19 pandemic on the social and economic situation in Africa. The data used in this paper was generated from online survey questionnaire, in which the participants were asked questions about how COVID-19 has affected their socio-economic lives. The questionnaire was designed to help Africa to understand COVID-19 impacts. The results reveal that COVID-19 affected Africa in the following ways: 1) 51.6\% responded that coronavirus affected their job search; 2) over the past three months, $47.1 \%$ of the respondents said their private financial situation remained unchanged; 3) 61\% did not trust the existence of COVID-19; 5) according to this online survey administered using Google form, $51.8 \%$ of the respondents said the services sectors are the most impacted sectors, followed by industrial sector, $31.3 \%$, and agriculture is least affected sector at $8.4 \%$. Policy implication is that it has serious impacts on socio-economics interactions.
\end{abstract}

\section{KEYWORDS}

Africa, Coronavirus Pandemic, COVID-19, Economic Sectors, Online Survey, Social Distancing

\section{INTRODUCTION}

This paper assesses the impacts of covid-19 on socio-economic situation in Africa. Coronavirus pandemic which had created from the Wuhan Province of China in last part of December 2019. It instigated increasing quickly in China and to other parts of the world through the movement of people in late 2019 and early 2020. The feast of COVID-19 pandemic pretentious economic undertakings in China, the Chinese economy came to a standstill. China is a major exporter of producer and consumer commodities to Africa, and the economic reduction in China is anticipated to have spillover effects for Africa through the deleterious effect on African trades that depend on deeply on China for the supply of primary and intermediate raw materials. The coronavirus crisis is affecting many African countries, and the number of confirmed cases have been rising rapidly with a particularly severe situation in South Africa, Egypt, Algeria, Morocco and Cameroon. Prior to the COVID-19 pandemic, maximum of the healthcare infrastructure in African countries had worsened. Ozili, P. K. (2020) reveal that African countries have been pretentious by the coronavirus pandemic, and the consequence was more severe for African regions related to other areas and increasing Covid-19 pandemic posh social interaction and 
economic activities through the imposed social distancing policies that have different points of severity in numerous African countries. Some private hospitals rejected to admit sick patients whereas public hospitals surpassed their volume. This pressured the government of some countries to build isolation centers in large open fields around the country; notably, football stadiums were converted to isolation centers in countries such as Cameroon and Nigeria. In African countries where good healthcare systems exist, the government had to scale-up intensive care units and provide more resources for hospitals and healthcare systems to control the spread of coronavirus. The plain social consequence of the coronavirus crisis was fingered through the burden of movement limitations in numerous African countries. These measures inevitably affected economic activities in African countries, and because of the peoples in African countries are not versatile to operate jobs from home and even the government lack certain understand and lack human capita based that have that knowledge to operate from home and contributes effectively and efficiency to the economic growth and development. Most central banks applied fiscal policy, monetary policy and exchange rate policy to stabilize the economic in both the long run and short dynamics.

The emergent coronavirus literature has discovered the effect of the coronavirus predicament by single-day data, two-day data etc. and they typically emphasis on a exact sector like tourism industry sector (Gossling et al., 2020), the mining sector as part of industrial sector (Laing, 2020), or the economy (Fernandes, 2020; Ozili and Arun, 2020; Fornaro and Wolf, 2020). first, this study contributes to the recent literature on the impact of coronavirus in society (e.g Fornaro and Wolf, 2020). The paper contributes to this literature by exploring the socio-economic effect of coronavirus in Africa by looking at the context that was not mention in the literatures such as the online research methodology. The second, it contributes to the literature that examines the impact of social policies on the well-being of individuals in society (e.g. Lunau et al., 2013; Jutz, 2015; Acevedo et al., 2014; Li et al., 2016; Holt-Lunstad et al., 2010; McGuire, 2011).

The main objective of the paper is to assess the impacts of covid-19 on the social-economic live and livelihoods of the people in Africa, specifically; 1) the sectors' that made up the economy, 2) perception of the people 3) social distancing 4) job search 5) Private financial situation, 6) prevention method of covid-19 pandemic etc. The paper follow this formatting. Section 2 presents the brief literature review. Section 3 current statistic of covid-19 in the World and Africa Section 4 the online research methodology. Section 5 the results. Section 6 concludes and policy implication.

\section{A BRIEF LITERATURE REVIEW}

A recent body of literature explores the impact of coronavirus on society. For instance, Chinazzi et al. Haleem et al. (2020) indication that COVID-19 has pretentious day-to-day life and is decelerating down the worldwide economy. They argue that the economic effects of coronavirus such as the slowing of the manufacturing of essential goods, disruption of the supply chain of products, losses in national and international business, poor cash flow in the market, significant slowing down in the revenue growth while the social consequences include the cancellation or postponement of large-scale sports and tournaments, disturbance of celebration of cultural events, religious and festive events social distancing, closure of hotels, bars and restaurants and religious places, closure of places for entertainment. Chen et al If migration increases by $0 \%$, economic growth in the Gambia will reduces by 1.8(Ceesay 2020). Ozili (2020) analyses the COVID-19 spillovers to Nigeria and finds that the existing structural weaknesses in Nigeria contributed to making the crisis more severe in the country.Fornaro and Wolf (2020), using a simple model, show that the coronavirus trigged a negative supply shock. Ramelli et al (2020) revealed that the health predicament distorted/transformed into an economic predicament which was augmented through financial channels. 


\section{COVID-19 STATISTICS AND IMMEDIATE MEASURES FOR CONTAINING ITS SPREAD}

\subsection{Covid-19 Update and its Impacts}

Globally, as of $21^{\text {st }}$ October 2020, there have been 40,665,438 confirmed cases of COVID-19, including $1,121,843$ deaths(WHO,2020). We can see still the virus is affecting millions of peoples by each day. As of $15^{\text {th }}$ October, 2020, confirmed coronavirus cases in Africa: 1,605,581, Recovered: 1,322,441; Confirmed coronavirus deaths: 38,837 (Africa CDC; Johns Hopkins; NCoVAfrica).

\subsection{COVID-19 Situation Update for the WHO African Region}

The number of coronavirus disease 2019 (COVID-19) cases in the WHO African Region is now at 1 232030 with 27684 deaths. This is a $20 \%$ increase in incidence cases and an $86 \%$ increase in deaths compared to 25840 cases and 659 deaths registered during the prior reporting period (30 September - 7 October 2020). In an alike trend to the preceding reporting period, 22 countries documented a decrease in new cases, with 15 registering a reduction of more than 20 percent. As of Figure 1 stated that the number of confirmed cases per million people is lower than the number of actual cases. The main reasons from European CDC is that there is limited testing for covid-19 pandemic from February, 2020 to October, 2020. To date, a total of 1043969 (85\%) case-patients reported from all the 47 countries have recovered. The total number of deaths reported in the region is 27684 , reported in 45 countries, giving an overall case fatality ratio (CFR) of $2.3 \%$. Two countries, including Eritrea and Seychelles, have not registered any COVID19 related deaths since the beginning of the pandemic.

Since the beginning of the outbreak in the region, the majority of the deaths have been reported from: South Africa 65\% (18 028), Algeria with 6.6\% (1 818), Ethiopia 4.7\% (1 305), Nigeria 4.0\% (1 116), Kenya 2.8\% (787), Cameroon 1.5\% (423), Zambia 1.2\% (344), Senegal 1.1\% (315), Ghana $1.1 \%$ (308), Democratic Republic of the Congo 1.0\% (276), and Madagascar 0.9\% (237). The top five countries: South Africa, Algeria, Ethiopia, Nigeria, and Kenya account for 83\% (23 054) of the total deaths reported in the region. Chad (7.0\%), Liberia (6.0\%), Niger (5.7\%), Mali (4.0\%), Algeria (3.4\%), Angola (3.3\%), and Gambia (3.2\%) have the highest country specific case fatality ratios.

\section{METHODOLOGY}

\subsection{Online Research Method}

The data use in this paper was generated from online survey questionnaire from June,2020 to October, 2020, in which the participants were asked about certain questions in which covid-19 affect their social-economic situation. The questionnaire was design to help Africa to understand covid-19 impacts on their daily live. Respondent were questions such as; Psychology-Behavior, altitude, perception, trust, lockdown, Agriculture, Energy sector, Job/employment/employee, Daily working, Economic, GDP, Social Impact-Ceremonial gathering.

The initial information was reviewed to understand the final information we put it as questions to increases quality and what information needed to be gather or not gather.

\section{RESULTS}

From Figure 1, 51.6\% responded in Africa that coronavirus affect their job search and while 45.2\% said it does not affect their job search and only small margin of $3.2 \%$ said maybe it affects or not. A continued lockdown not only causes risks to regaining jobs, but it also causes jobs seeking or finding extreme difficult. In African, contrast to others developed countries, there is lack of knowledge and tools to operate and use adequately information communication technology (ICT) and research and development (R\&D) to communicate and use it as a tools to work from homes. In additional, most 
Figure 1. Job search and COVID-19 pandemic June, 2020 to October, 2020 (Source: Author Compilation from Google form for online survey)

\section{Did coronavirus affect your job search? \\ 31 responses}
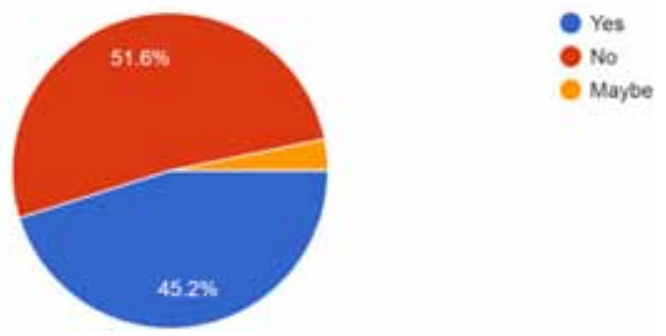

companies cannot lack knowledge in ICT. So, the lower output makes most of the companies to reduce workers. Even Africa's companies can do work from homes, the fluctuations of electricity in most of the countries in Africa will not allow to have continue works online and in that cases this will discourages most of the companies not to hire more workers due to ineffectiveness and inefficiencies and lack of productivity they will brings to the companies. In the part, jobs seekers will have no alternative sources of income, so food insecurity will be high and this will eventually increases the level of unemployment rates in Africa and the decline in overall economic output.

From Figure 2, 59 out of 105 respondent i.e. 56.2 percent of the respondent said they live with children that are below the age of 18 years and 21.9 percent said they do not do the following; live alone, live with children under 18, live with people in a COVID-19 risk group (people over 65 years and/or with chronic disease).In Africa, if most live with covi19 risk peoples, it will causes huge lost to the entire population, the study noted due to lack of proper health care facilities, lack of adequate human capital formation and high level of poverty and debt. In Africa, even the climate change can causes the virus to easily spread due to lack of good environmental places, lack of good drinking water and lack of good cleaning of the surrounding, poor energy supply for the population etc. The virus spread differently like through toughing noise, mouth, faces, hand. As most African countries have poor environment and dirty surrounding, the virus will easily spread as well. Note that this does not mean that the virus cannot spread through other means such as gathering together without observing social distancing principle. Another important prediction maybe in the long run this coronavirus will

Figure 2. Household and COVID-19 pandemic June 2020 to October 2020 (Source: Author Compilation from Google form for online survey)

Who lives in your household besides yourself?Choose as many as apply

105 responses

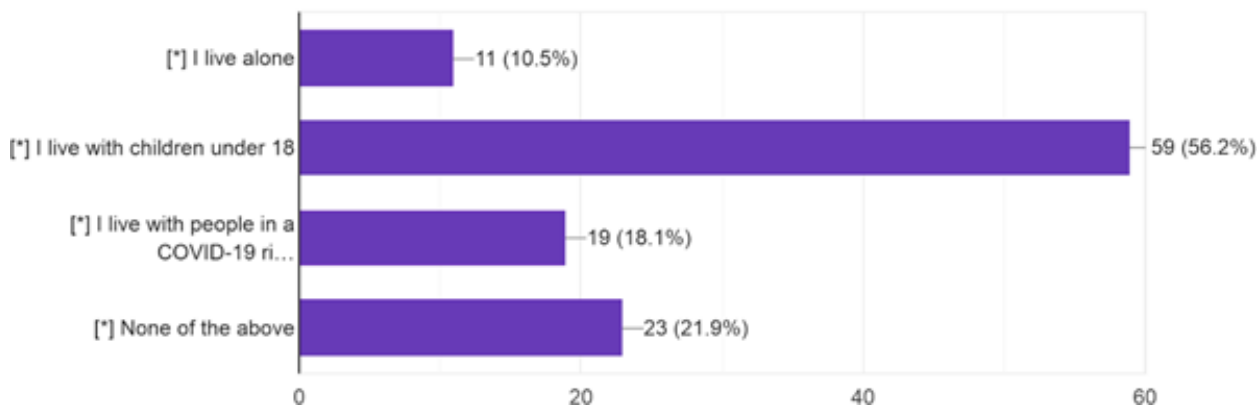


hurt Africa more because lack of proper health facilities and lack of human capital and high debt to GDP ratios and this will hurt the economic growth for a longer period of time.

From Figure 3, Over the past three months, 47.1 percent of the respondents in Africa said their private financial situation remain unchanged/remains the same. This is due to the fact that most of those peoples' is either privately working for themselves or working for governments or private sectors that do not reduces their workers incomes. This we mean that they have job security. So financially, there income remains the same whatever the circumstances or situation they find themselves excluding conflicts, displacement, climate change effects such as drought, flooding, sea-level rises, salt water intrusion, bushfire, salinization, pollution, erratic rainfall, high temperature etc. and wars. These variables will change their incomes and will make to them to migrates elsewhere either temporary or permanent, in-migration or out-migration and obviously there private financially situation will be worsen during the covid-19 pandemic. 38.5 percent of the respondent said, there private financial situation became worse during the last three months of covid-19. This of course associated with lockdown negative impact on jobs, petty businesses or informal sector businesses, community fishing businesses, farming either livestock or crop production, hunting etc. Most of the peoples that are doing the above business(es) due to closure of markets and lockdown of most of places and even lack of access to street all of them causes lack of finance and that will have negative impacts of their financial situation.

From Figure 4, According to the survey, 35.2 percent said they know people in their social environment who are infected with this pandemic disease and the large respondent of 64.8 percent said they did not know people in their immediate social surrounded who are or have been infected with COVID-19. This large gaps maybe due to the fact that peoples did not believe entirely that coronavirus exist especially in Africa in which most of the peoples believe in traditional medicine than modern medicine. Most of peoples said in Africa that coronavirus is in Europe and not in Africa, Most locals peoples that are interviewed by media said they have not seen anyone who can show you coronavirus is real. Some said it is just that our government is lying to us. Some even said up to a point that, they are using it to defraud the masses, who are already suffering from other health issues, food insecurity, hunger, malnutrition, poverty and etc. In Africa, trust between peoples and government are the mainly causes of not believing the existing of covid- 19 . This is confirmed in this survey study that is done using Google form.

From Figure 5, most of the peoples in Africa did not trust the true existing of the Covid-19, ninetyeight peoples that responded to this part of the survey, approximately 61 percent said they did not know anyone who die from covid-19, while closely estimate of 32 percent said they known someone

Figure 3. Private financial situation and COVID-19 pandemic June, 2020 to October, 2020 (Source: Author Compilation from Google form for online survey)

Please assess your private financial situation over the past three months: 104 responses
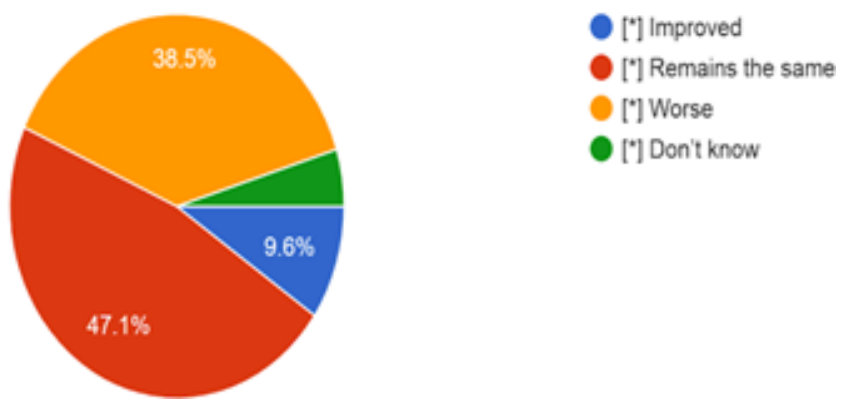
Figure 4. Social environment and COVID-19 pandemic June 2020 to October 2020 (Source: Author Compilation from Google form for online survey)
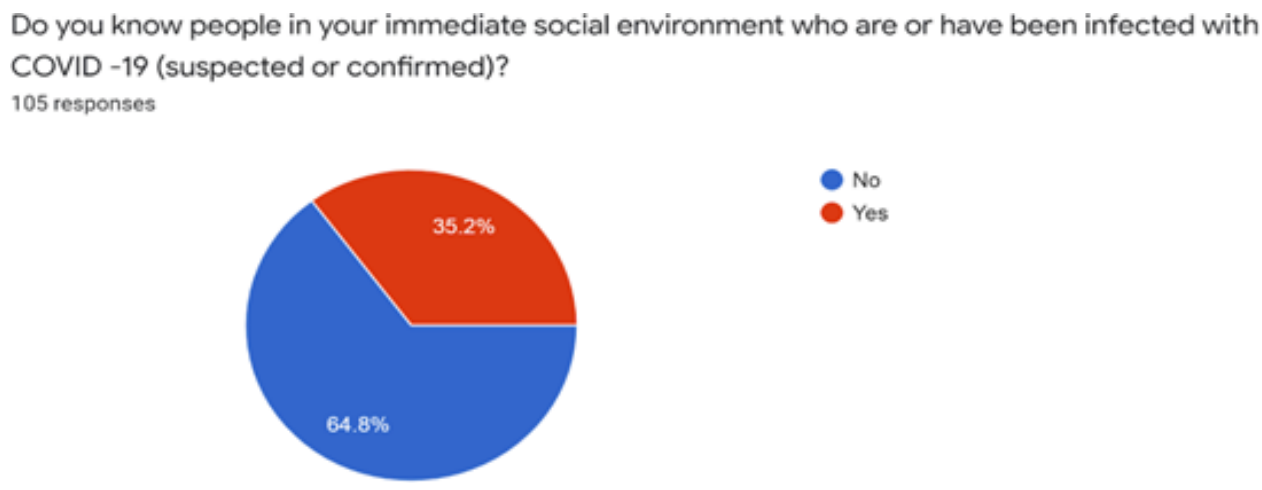

Figure 5. Death and COVID-19 pandemic June 2020 to October 2020 (Source: Author Compilation from Google form for online survey)

$$
\begin{aligned}
& \text { do you know someone who died from COVID-19? } \\
& 98 \text { responses }
\end{aligned}
$$
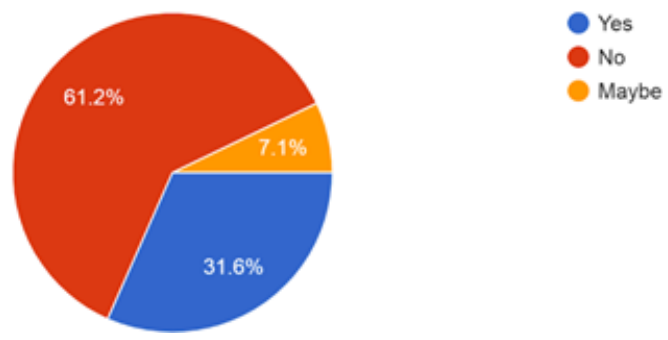

who died from covid-19 and 7.1 percent did not actually believe that covid-19 killed someone they known. This is attributed to that peoples in most part of Africa are not well inform, did not trust the information about covid-19 or did not trust their government and health sectors.

From Figure 6, In Africa according to this online survey administered using Google form 93.2 percent know how to protect themselves from covid-19. This mean that most of peoples that respondents to this survey knows the prevention mechanism of covid-19 such as; Clean your hands often by Using soap and water, or an alcohol-based hand rub, Maintain a social distance from anyone

Figure 6. Prevention and COVID-19 pandemic June, 2020 to October, 2020 (Source: Author Compilation from Google form for online survey)

Do you know how to protect yourseif from coronavirus?

103 responses

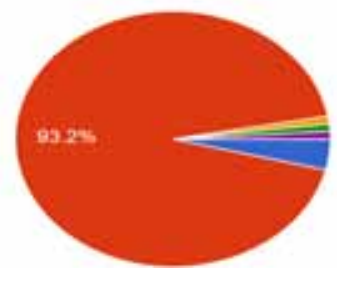

Net at alt

Very much so

Beiry optimistic based on the

information at hand

Tiake care of your body and he will take

core of you

- I think ido 
who is coughing or sneezing, Wear a mask when physical distancing is not possible, Don't touch your eyes, nose or mouth, Cover your nose and mouth with your bent elbow or a tissue when you cough or sneeze, Stay home if you feel unwell., and If you have a fever, cough and difficulty breathing, then seek medical attention. According to this online survey only 3.9 percent said they did not know at all how to protect themselves from covid-19 pandemic, while only 1 percent said they are being optimistic about the information at hand that they know how to protect themselves from coronavirus.

From Figure 7, Most of the peoples in Africa said it is extremely difficult to avoid an infection with covid-19 pandemic at current situation 61.6 percent. In fact extremely difficult to avoid an infection of covid-19 in Africa is due to; almost all types of transportation in Africa are overcrowded-the close proximity of passengers and frequently handing of money makes coronavirus to spread, Peoples still goes to different gathering such as ceremonies, mosques, churches etc., continue visiting market and lack of continue hand washing, increases in physical contact, lack of trust most have in Africa about covid-19, also have serious consequence in Africa.

From Figure 8, Those of the peoples who responded to the online survey, 80.8 percent said they use antibiotics to prevent or treat covid-19, while 64.4 percent said they avoid going to crowded places, 47.1 percent said they use clean their hands frequently, the least measure to prevent covid-19 Africa is use immune boosters tablets.

From Figure 9, in Africa, 64 percent trust health care workers to get the information about coronavirus and 3 percent do not trust health care workers, follow by ministry of health-54 percent and 13 percent do trust ministry of health in Africa, follow by information from television- 45 percent and 7 percent do not trust television too. Surprising results, 25 percent in Africa trust social media

Figure 7. Avoiding an infection and COVID-19 pandemic June, 2020 to October, 2020 (Source: Author Compilation from Google form for online survey)

For me avoiding an infection with COVID-19 in the current situation is... 99 responses

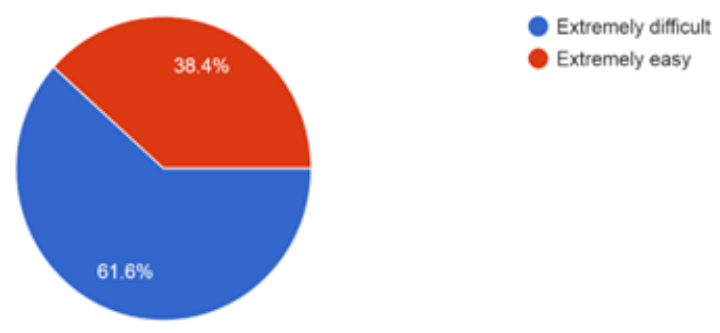

Figure 8. Measure to prevent and COVID-19 pandemic June, 2020 to October, 2020 (Source: Author Compilation from Google form for online survey)

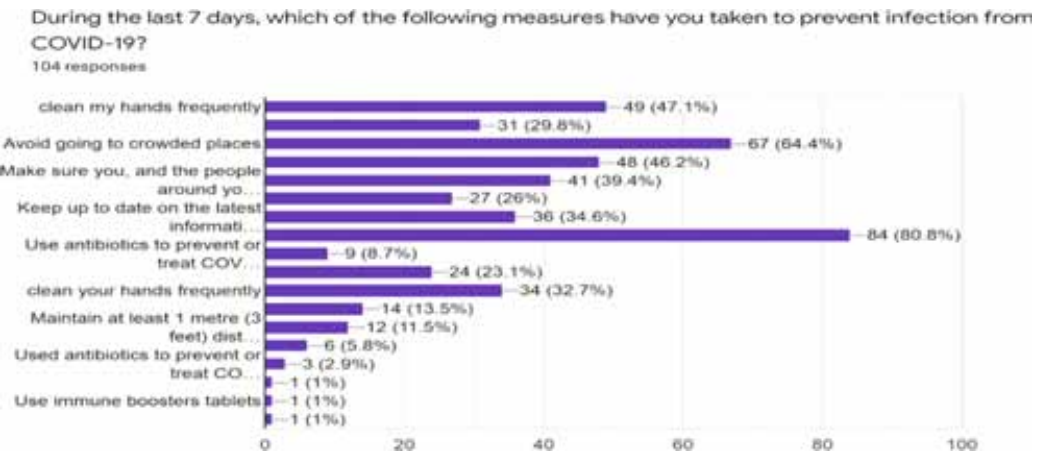


Figure 9. Information and COVID-19 pandemic June, 2020 to October, 2020 (Source: Author Compilation from Google form for online survey)

How much do you trust information about COVID-19 from the following sources?

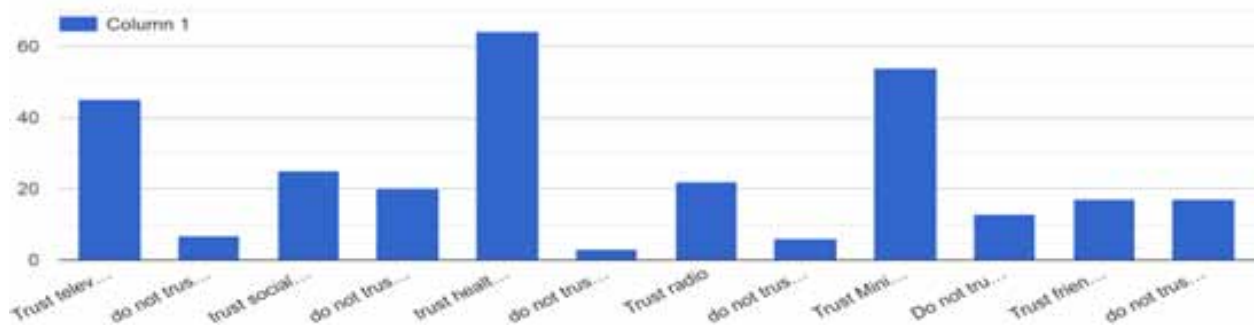

while 20 percent do not trust social media. The gap of trust (trust minus do not trust) in social media in Africa according to the result of this online survey stand at 5 percent. Majority of the peoples do not trust the media outlet that update the outcomes of covid-19 and its existence especially in Africa, the study noted.

From Figure 10, in Africa, 51.8 percent of the respondents said services sectors are most impacted sector during covid-19 pandemic. This is due to the fact most of the sectors that belong to these sectors such as IT sectors, tourism sectors, health sectors, and educational sectors. They are all affected because of barrier to travels making tourism contribution to tax revenue reduces drastically and in most of the countries in Africa tourism is one of the main contributor to their economic, if it reduces, it contribution to revenue and economic and even the contribution to societies also reduces especially transportation services for them as well. As restriction make transportation from place to place difficult and that also affect the services sector contribution to GDP and for the IT sectors as one of the service sectors and most important sectors in Africa is impacted during pandemic because most of the jobs should be operate from homes as do the western countries but in Africa most of the workers lack knowledge and skills to operate work from home due to lack of electricity both renewable energy and non-renewable energy and they impact negatively to economic growth due low investment and high consumption those sectors as well.31.3 percent respondents said industria sectors are the most impacted sector during pandemic. This is attributed to the fact industrial sectors during this pandemic especially airline industries, clothing induestries, automobile induestries, vehicle industries, retail industries, manufacturing industries are all affected one way or the others either production, distribution and final to reach at the customers due to travel ban. If industries is not working well, that will make that industries to reduces it worker to have capture with the capita to be able to pay the

Figure 10. Sectors and COVID-19 pandemic June, 2020 to October, 2020 (Source: Author Compilation from Google form for online survey)

Which sectors are being most impacted byCOVID-19 ?

83 responses.
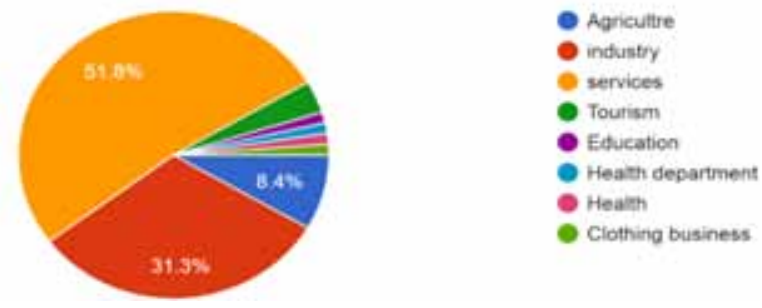
remaining workers. In china for example in which most of the African mobile or other clothing are made and as they are affected, the export reduces their economic by net export and import in Africa continue to reduces their economy both before pandemic and during pandemic. In Africa, according to the respondents agriculture is least sector affected during pandemic at 8.4 percent. Service sector affect through worker productivity, employment, revenue, education closure, fragile health facilities in Africa, lockdown customers reduces deposit in the banks too and lockdown while industrial sector affected through processing, employment, distribution, supply chain, revenue/output and level of raw material also reduces and finally agricultural sectors divided into fishing, crop production, livestock production, horticulture, hunting, forestry are all affected through lack of laborers, transportation and marketing to reach at the final customers decline, food prices reduces, distribution and production halt down, households that depend on fishing, livestock and crop production have negative effect on them because of lockdown. Quality of education SDGs number 4, Poverty SDGs number 1 and Hunger SDGs number 2 all will be affected negatively during lockdown because most of the schools in Africa cannot do proper online classes and hence they lack necessary tools to interact and solve certain complex problem such as quantitative issues and courses that needs practical training and that affect the performances of student and overall quality of education reduces. Tourism is affected through border closure and travel bans and that affects both countries of origin and countries of destination and affects overall migration and remittance especially in Africa, where majority of youth are migrated to western countries.

\section{CONCLUSION AND POLICY IMPLICATION}

Assesses the covid-19 and its effect on the economics of Africa by looking at the people's perception and social-economic situation in Africa. As the results generated, most people said coronavirus will affect African countries even in the future due to the fact that African countries do not have proper human capital to deal with this pandemic and due to lockdown most of the revenue and products are drive from tourisms and china, due to services sector and industrial sector that are mostly affected. As lockdown rises and travels ban affects the tourism sectors and it makes Africa vulnerable and that contribution to tourism sector decline and that reduces the overall economic growth in the last quarters of 2019 and the whole year of 2020.The most peoples that answer to this online survey said coronavirus affect their daily life such as job search, the economic sectors, income, employment, consumption etc.

The policy implication of covid-19 as indicated in this survey is that, most of the countries in Africa depend on agricultural sectors and that are least sectors affected by covid-19. This have serious impacts on social-economics interactions. If social-economic interaction decline, this will eventually causes trade, exchange of goods and services to slow-down and eventually will have negative impacts on economics through lack of exchange rates, import, export, net-export per se, balance of payment, investment, consumption, saving, agriculture, causes high commodity prices, debt to GDP ratios to be high, climate change effects affect livelihoods and agriculture productivity will decline through crops failures and low productions in fishing and livestock industries, high co2 emission will affect national parks, wildlife and forests', poverty, food insecurity and hunger will rises due to insufficient demand of food stuffs items because of low import and poor agriculture, the domestic and international migration will be reduces, remittances reduces and those left behind are seriously affected in terms of health, food security, education especially women, children, elderly and disable that are left behind and this will have negative consequences on economic growth and development. This may be attributed to lack of exposure to this for export to others countries. As we export less in agricultural sector, that made it less vulnerable compare to industrial or service sector. As we import most of products from china and western countries so this make most industrial sector or manufacturing sector such as clothing sector, author mobile sector, car sector, to be affected totally and this affects daily interaction with the outside world. Total imports granger caused growth 
and growth granger caused import in the Gambia (Ceesay et al. 2019).As service sector is the sector that is seriously affected in Africa, it workers decline and its services remain stagnated. As for now and in the future covid-19 pandemic will affects Africa in both short term and long term by lack of trust with the governments, lack of proper information about covid-19, continue observing social gathering, do not follow health care advice and etc.

\section{ACKNOWLEDGMENT}

All procedures performed in studies involving human participants were in accordance with the ethical standards of the institutional and/or national research committee and with the 1964 Helsinki declaration and its later amendments or comparable ethical standards.

Informed consent: Informed consent was obtained from all individual participants included in the study. 


\section{REFERENCES}

Ceesay, E. (2020). Employment in Agriculture, Migration, Bilateral Aids, Economic Growth and Remittance: Evidence from the Gambia. Economics, Management and Sustainability. doi:10.14254/jems.2020.5-1.5

Ceesay, E. K., Belford, C., Fanneh, M. M., \& Drammeh, H. (2019). Relationship between Export, Imports and Economic Growth: An Export-led Growth Strategy for the Gambia Using The Granger Causality Test. International Journal of Social Sciences Perspectives. 10.33094/7.2017.2019.42.38.47

Chinazzi, M., Davis, J. T., Ajelli, M., Gioannini, C., Litvinova, M., Merler, S., Pastore y Piontti, A., Mu, K., Rossi, L., Sun, K., Viboud, C., Xiong, X., Yu, H., Elizabeth Halloran, M., Longini, I. M., \& Vespignani, A. (2020). The effect of travel restrictions on the spread of the 2019 novel coronavirus (COVID-19) outbreak. Science, 368(6489), 395-400. Advance online publication. doi:10.1126/science.aba9757 PMID:32144116

Fernandes, N. (2020). Economic effects of coronavirus outbreak (COVID-19) on the world economy Nuno Fernandes Full Professor of Finance IESE Business School Spain. SSRN Electronic Journal.

Fornaro, L., \& Wolf, M. (2020). Covid-19 Coronavirus and Macroeconomic Policy. CEPR Discussion Papers.

Fornaro, L., \& Wolf, M. (2020). Covid-19 Coronavirus and Macroeconomic Policy : Some Analytical Notes. Barcelona GSE Working Paper Series.

Gössling, S., Scott, D., \& Michael Hall, C. (2020). Pandemics, Tourism and Global Change: A Rapid Assessment of COVID-19. Journal of Sustainable Tourism. Advance online publication. doi:10.1080/09669582.2020.1758708

Haleem, A., Javaid, M., \& Vaishya, R. (2020). Effects of COVID-19 pandemic in daily life. Current Medicine Research and Practice., doi:10.1016/j.cmrp.2020.03.011

Laing, T. (2020). The economic impact of the Coronavirus 2019 (Covid-2019): Implications for the mining industry. Extractive Industries and Society. doi:10.1016/j.exis.2020.04.003

Ozili, P. (2020). COVID-19 in Africa: Socio-economic impact, policy response and opportunities. The International Journal of Sociology and Social Policy. Advance online publication. doi:10.1108/IJSSP-05-2020-0171

Ozili, P. K. (2020). COVID-19 pandemic and economic crisis: the Nigerian experience and structural causes. Journal of Economic and Administrative Sciences. https://doi.org/10.1108/jeas-05-2020-0074

Ozili, P. K. (2020). COVID-19 pandemic and economic crisis: the Nigerian experience and structural causes. Journal of Economic and Administrative Sciences. https://doi.org/10.1108/jeas-05-2020-0074

Ozili, P. K., \& Arun, T. (2020). Spillover of COVID-19: Impact on the Global Economy. SSRN Electronic Journal. $10.2139 /$ ssrn. 3562570

Ramelli, S., \& Wagner, A. F. (2020). Feverish Stock Price Reactions to COVID-19*. The Review of Corporate Finance Studies. https://doi.org/10.1093/rcfs/cfaa012

WHO. (2020). Novel Coronavirus (2019-nCoV) Situation Report - 1. Who. 


\section{APPENDIX}

\section{Table 1. Google form questionnaire format}

\begin{tabular}{|c|c|}
\hline $\begin{array}{l}\text { Which sectors are being most impacted } \\
\text { byCOVID-19? }\end{array}$ & Did coronavirus affect your job search? \\
\hline Agricultre & Yes \\
\hline industry & No \\
\hline services & Maybe \\
\hline \multicolumn{2}{|l|}{$\begin{array}{l}\text { What do you consider to be your own probability of } \\
\text { getting infected with COVID-19? }\end{array}$} \\
\hline Extremely Unlikely & What is your sex? \\
\hline Extremely Likely & Prefer not to say \\
\hline Clear selection & male \\
\hline $\begin{array}{l}\text { How susceptible do you consider yourself to an } \\
\text { infection with COVID-19? }\end{array}$ & female \\
\hline Not at all susceptible & How many years of education have you completed? \\
\hline Very susceptible & [*] 0-9 years \\
\hline $\begin{array}{l}\text { How severe would contracting COVID-19 be for } \\
\text { you (how seriously ill do you think you will be)? }\end{array}$ & [*] 10-12 years (secondary school completed) \\
\hline Not severe & {$[*]$ more than 12 years } \\
\hline Very severe & Other: \\
\hline \multicolumn{2}{|l|}{$\begin{array}{l}\text { Do you know how to protect yourself from } \\
\text { coronavirus? }\end{array}$} \\
\hline Not at all & $\begin{array}{l}\text { Who lives in your household besides yourself? Choose as many } \\
\text { as apply }\end{array}$ \\
\hline Very much so & [*] I live alone \\
\hline \multirow[t]{2}{*}{ Other: } & [*] I live with children under 18 \\
\hline & $\begin{array}{l}{[*] \text { I live with people in a COVID-19 risk group (people over } 65} \\
\text { years and/or with chronic disease) }\end{array}$ \\
\hline $\begin{array}{l}\text { For me avoiding an infection with COVID-19 in the } \\
\text { current situation is... }\end{array}$ & {$[*]$ None of the above } \\
\hline Extremely difficult & $\begin{array}{l}\text { Please assess your private financial situation over the past three } \\
\text { months: }\end{array}$ \\
\hline Extremely easy & [*] Improved \\
\hline $\begin{array}{l}\text { During the last } 7 \text { days, which of the following } \\
\text { measures have you taken to prevent infection from } \\
\text { COVID-19? }\end{array}$ & [*] Remains the same \\
\hline clean my hands frequently & {$[*]$ Worse } \\
\hline $\begin{array}{l}\text { Maintain at least } 1 \text { metre ( } 3 \text { feet) distance from } \\
\text { others }\end{array}$ & [*] Don't know \\
\hline Avoid going to crowded places & $\begin{array}{l}\text { To your knowledge, are you, or have you been, infected with } \\
\text { COVID-19? }\end{array}$ \\
\hline Avoid touching eyes, nose and mouth & {$[*]$ No } \\
\hline
\end{tabular}




\section{Table 1. Continued}

\begin{tabular}{|c|c|}
\hline $\begin{array}{l}\text { Make sure you, and the people around you, follow } \\
\text { good respiratory hygiene. }\end{array}$ & {$[*]$ Yes } \\
\hline $\begin{array}{l}\text { Stay home and self-isolate even with minor } \\
\text { symptoms such as cough, headache, mild fever, } \\
\text { until you recover }\end{array}$ & If "yes": \\
\hline $\begin{array}{l}\text { Keep up to date on the latest information from } \\
\text { trusted sources, such as WHO or my local and } \\
\text { national health authorities }\end{array}$ & Was it: \\
\hline Wearing masks & [*] Mild \\
\hline Use antibiotics to prevent or treat COVID-19 & [*] Severe \\
\hline Disinfect surfaces & Was it: \\
\hline Other: & [*] Confirmed by a test \\
\hline $\begin{array}{l}\text { What do you consider to be your own probability of } \\
\text { getting infected with COVID-19? }\end{array}$ & [*] Not confirmed by a test \\
\hline Extremely Unlikely & Yes \\
\hline Extremely Likely & $\begin{array}{l}\text { Do you know people in your immediate social environment } \\
\text { who are or have been infected with COVID - } 19 \text { (suspected or } \\
\text { confirmed)? }\end{array}$ \\
\hline & No \\
\hline $\begin{array}{l}\text { How susceptible do you consider yourself to an } \\
\text { infection with COVID-19? }\end{array}$ & Yes \\
\hline Not at all susceptible & do you know someone who died from COVID-19? \\
\hline Very susceptible & Yes \\
\hline $\begin{array}{l}\text { How severe would contracting COVID-19 be for } \\
\text { you (how seriously ill do you think you will be)? }\end{array}$ & No \\
\hline Not severe & Maybe \\
\hline Very severe & How easy do you have information about cov $19 ?$ \\
\hline \multicolumn{2}{|l|}{ Do you know how to protect yourself from coronavirus? } \\
\hline Easy & \\
\hline
\end{tabular}

